\title{
Borderlands, Primary Sources, and the Longue Durée: Contextualizing Colonial Schooling at Odanak, Lorette, and Kahnawake, 1600-1850
}

\author{
Thomas Peace \\ Huron University College
}

\begin{abstract}
The historiographies of Indigenous engagement with colonial-style schools and colleges in New England, New York, and New France have different trajectories. In New England and New York, as colonial settlers expanded onto their lands over the eighteenth century, members of the Mohegan, Narragansett, Pequot, and Kanien'kehá:ka (Mohawk) nations built schools. In New France - where colonial expansion happened much more slowly - historians suggest that interaction with formal schooling stopped as the demographic balance shifted to favour the French settlers occupying Abenaki, Algonquin, Innu, Kanien'kehá:ka, and Wendat lands. By examining the deployment of colonial schooling over an Indigenous landscape during the seventeenth and eighteenth centuries, this paper makes some tentative arguments about how these divergent historiographies might be stitched together, emphasizing how access to schooling has been a continuous and central site of contest between Indigenous and colonial societies since the very beginning of the colonization of northeastern North America by England and France. Only in the late eighteenth century - when colonial pressures on land and resources were acutely felt — were these ideas taken up directly within Indigenous communities to such an extent that schools were built and teachers trained.
\end{abstract}

\section{RÉSUMÉ}

Les historiographies de la relation des Autochtones avec les écoles et collèges coloniaux de la Nouvelle-Angleterre, de New York et de la Nouvelle-France ont emprunté des trajectoires différentes. En Nouvelle-Angleterre et à New York, les membres des nations Mohegan, Narragansett, Pequot, et Kanien'kehá:ka (Mohawk) ont construit des écoles au fur et à mesure que les colons empiétaient sur leurs terres au cours du XVIII ${ }^{e}$ siècle. En Nouvelle-France, où l'expansion coloniale s'est produite beaucoup plus lentement, les historiens suggèrent plutôt que l'interaction avec l'enseignement scolaire s'arrête lorsque l'équilibre démographique bascule en faveur des colons français occupant les territoires des Abénakis, des Algonquins, des Innus, des Kanien'kehá:ka, et des Wendats. En examinant la mise en place de l'école coloniale dans le paysage autochtone au cours des $\mathrm{XVII}^{e}$ et XVIII ${ }^{e}$ siècles, cet article propose quelques hypothèses sur la façon dont ces historiographies divergentes pourraient être assemblées, en soulignant comment l'accès à l'enseignement a été un lieu central et continu de contestation entre les sociétés autochtones et coloniales depuis le tout début de la colonisation du 
nord-est de l'Amérique du Nord par l'Angleterre et la France. C'est seulement vers la fin du XVIII siècle - lorsque les pressions coloniales sur le territoire et les ressources ont été vivement ressenties - que ces idées ont été reprises directement par les communautés autochtones, au point que des écoles ont été construites et que des enseignants ont été formés.

In 1929, a handful of professors from Dartmouth College in Hanover, New Hampshire, made a special trip two hundred miles north to the Abenaki community of Odanak in the Canadian province of Quebec. The professors were at Odanak to visit "Little Dartmouth," a century-old day school created in 1803 by François Annance, one of Dartmouth's Abenaki students. ${ }^{1}$ By the time the faculty arrived at Little Dartmouth, the connection between Odanak, the college, and its preparatory school - Moor's Indian Charity School — was well over 150 years old. Abenaki from the community began attending the school in the mid-1770s following two transformative events: the flood of Anglo-American settlement onto their lands following the British conquest of New France and the impending demise of the Jesuit order (which was active in the community until shortly after the Vatican suppressed it in 1773). ${ }^{2}$

Much like the Abenaki, the Wendat at Jeune-Lorette, just thirteen kilometres from Quebec City and 160 kilometres from Odanak, also had a day school in the early nineteenth century; another college alumni had established it a decade earlier. Although they had different languages, cultures, and experiences of French and British colonialism, the fact that both the Abenaki and Wendat attended the charity school and also created community schools at about the same time suggests some important commonalities. ${ }^{3}$ Each school, for example, was relatively well attended - by both boys and girls. Although at Odanak less than half the village children attended regularly, at Lorette there was nearly universal attendance. ${ }^{4}$ Similarly, the founding teachers spent considerable time studying at either the charity school or college. Louis Vincent, known to the Wendat as Sawatanen, attended the college for nine years, graduating in $1781 .{ }^{5}$ We know less about Annance, who did not complete his studies but spent six years split between the charity school and the college, leaving in the early 1780 s. $^{6}$ Their experiences were not entirely unique. Between 1770 and 1820, thirty-three children from the St. Lawrence valley attended Moor's Indian Charity School, some of whom also went on to teach school. ${ }^{7}$ These schools shared much in common with the better known day schools operating at the time in Kanien'kehá:ka (Mohawk) communities on the Bay of Quinte and Grand River; there too, schools were taught by community members and claimed to have been relatively well attended. ${ }^{8}$

These circumstances, anchored as they were in both the expansion of Anglo settlement following the Seven Years' War, but also the corresponding demise of the Jesuit order, suggest a need to revisit the eighteenth-century context within which these decisions were made. In this paper, I extend Jean-Pierre Sawaya's and Jean Barman's separate arguments about the important place of New England captives in determining whether young men from the broader alliance that united Indigenous communities in the St. Lawrence valley, known as the Seven Fires Confederacy, would attend Moor's Indian Charity School, by suggesting that the creation of these schools should 
also challenge us to re-examine the seventeenth- and eighteenth-century history of Indigenous engagement with colonial schooling and settler colonialism. ${ }^{9}$

In so doing, I do not want to be mistaken for emphasizing Catholic or Protestant missionary successes. Both the Jesuits and the charity school - institutions central to the arguments in this paper - situated their work within a logic of radical Indigenous social, cultural, and political assimilation. The peoples they targeted almost universally rejected these goals. Rather, the argument here takes a broader chronological and spatial perspective to point to continuities and persistence within missionary efforts that - when brought into conversation with unprecedented settler expansion - likely fostered conditions upon which schooling was decided as one potential tactic to ensure community survival in the face of eroding land and resources. The creation of schools within Indigenous communities was brought about not so much by a desire to replicate colonial society as much as it was a response to it. Taking this perspective reorients our focus away from missionary efforts and towards a more nuanced understanding of how people living in these missionary-allied communities navigated their everyday lives.

\section{Reorienting the Historiography}

Historians of education in the seventeenth- and eighteenth-century St. Lawrence valley have generally defined this period as a nadir in colonial efforts to school Indigenous peoples. Although the literature on this subject is small, historians have generally declared formalized efforts to teach Indigenous students a failure by the end of the seventeenth century. ${ }^{10}$ Likewise, due to their small population size, broad studies of literacy in the French colony often ignore these communities; when they include them (without making methodological accommodations) they suggest that Indigenous peoples were illiterate. ${ }^{11}$ Those historians who focus more specifically on education within the missions, oriented more towards religion and culture than education and schooling, emphasize its predominantly religious, rather than secular, nature. For them, missionary education involved instruction in catechism, abstinence from meat, and the abolition of practices that contradicted Catholic teaching. ${ }^{12}$ Most of these studies have focused more on the missionaries delivering the education than the Indigenous students engaging with it. ${ }^{13}$

There are five reasons why we know little about Indigenous schooling during the eighteenth and early nineteenth centuries. First, most studies of this period rely on the rich source material found in the Jesuit Relations and similar missionary records. The systematic recording of life in the Catholic missions in the St. Lawrence valley ends in the last decades of the seventeenth century; the Jesuit Relations ceased to be published for public consumption in $1673 .{ }^{14}$ With significantly less source material providing insight into these communities over the rest of the French regime, it is not surprising that most studies conclude that formal colonial attempts to school Indigenous populations diminished. ${ }^{15}$ Evidence from the end of the eighteenth century, after the British had captured Canada, suggests, however, that perhaps rather than a reduction in engagement with European structures of education, many of the 
patterns seen in the earlier period continued. Although efforts to create boarding schools certainly declined with the eighteenth century, more local sites of colonial interaction were sustained.

Second, historians have focused too narrowly on parameters set by the contemporary nation-state. In the United States, scholars study the schooling of Indigenous students at America's earliest colleges, particularly Harvard, William and Mary, and Dartmouth. ${ }^{16}$ Their studies are limited in geographical focus and do not examine similar and parallel developments in the seminaries of New France and in the communities along the shores of the St. Lawrence River and the Great Lakes. In Canada, for the reasons already articulated, the literature is sparse. Most emphasize requests for education in the early- to mid-nineteenth century and the subsequent creation of residential schools. ${ }^{17}$ But for most people before the mid-nineteenth century - especially the Abenaki, Haudenosaunee, and Wendat - the Canada-US border was relatively meaningless. Taking Indigenous territory seriously, we find that institutions like the charity school and the Petit Seminaire in Quebec could (and did) fall within the same cultural sphere of influence defined by Indigenous relationships with the Land. ${ }^{18}$ Expanding our geographical scope to include the lands now considered New England, New York, and Quebec reveals patterns that are harder to see from within these political jurisdictions.

Third, historians approach this subject through an institutional or biographical lens. Accordingly, we learn about institutions such as the charity school, whose initial mandate was to provide schooling for Indigenous peoples, or we learn about key personalities such as Samson Occom, the well-known Mohegan educator who himself attended a charity school. ${ }^{19}$ Whether intentional or not, these histories are often bound by colonial definitions of place, institution, and culture. They tend to fit into pre-established patterns of schooling that define its meaning through colonists' actions. Although this is changing quickly, in doing so, the tendency has been to present Indigenous intellectuals as exceptional rather than fitting within a broader cultural sphere of teaching and learning and emerging settler colonial hegemony.

Lisa Brooks's The Common Pot and Linford Fisher's The Indian Great Awakening point towards a more nuanced approach. Rather than looking at larger colonial institutions and missionary-led structures of education, these two scholars emphasize local engagement with schooling as a strategy to gain autonomy in an intensifying colonial world. ${ }^{20}$ According to their research, institutions like the charity school were relatively insignificant in comparison to local day schools, which were well underway by the time Eleazar Wheelock commenced his educational project. According to Fisher, between 1754 and 1770, only twenty-nine children sought out instruction at the charity school, while local day schools - often, but not always, taught by an Indigenous teacher-were far better attended. In the mid-eighteenth century, the school at Stockbridge had about fifty-five Mohican students, the one at Mashantucket had thirty, and the school at Narragansett had fifty-three pupils. ${ }^{21}$ Likewise, the Kanien'kehá:ka also had at least one school at this time - taught by the well-known schoolteacher Paul Sahonwagy and attended by about forty students — while during the 1780s and 1790s, school was taught both at Grand River 
and on the Bay of Quinte. The school at Grand River reported having sixty-six students in attendance in 1792. ${ }^{22}$ Similar schools were built in a number of Anishinaabe communities in the lower Great Lakes region during the 1820 s and 1830 s. ${ }^{23}$ Despite the range of cultures and contexts, in almost every case listed here, schools were created when the demographic balance began to favour colonial settlers.

Fourth, a too rigid association of Indigenous peoples with oral traditions abstracted from relationships with material objects and practices of reading, writing, and inscription risks blinding us to more subtle evidence related to schooling, alphabetic literacy, and their political uses. ${ }^{24}$ Brooks's work illustrates the importance of situating writing within these contexts. For her, written documents served as "an instrumental tool for the reconstruction of 'Native space' and for resistance to colonization." ${ }^{25}$ In her analysis of Samson Occom, Joseph Brant, Hendrick Aupaumut, and William Apess, Brooks reveals how writing was embedded within longstanding northeastern cultural practices and the very real social, political, and territorial pressures of the eighteenth and nineteenth centuries. Although she only indirectly explores the nature of schooling, my arguments build upon hers: understanding the cultivation of alphabetic literacy within a continuum of allied practices and understandings and also situating schooling as a negotiated experience related directly to maintaining rights to the Land.

Finally, although gender relationships are central to her analysis, Brooks's book focuses primarily on male writers. Hilary Wyss's similar work on women who could write but chose not to draws our attention to the conditions under which one might choose to write. Just because someone knew how to write does not mean that they deployed this skill publicly or valued it as important. ${ }^{26}$ In her analysis of the lives of Mary Occom and Sarah Simon, Wyss points to a handful of letters written by these women to demonstrate the silences brought about by their active decision not to write. Part of my argument in this article hinges on the similar possibility that writing skills went undocumented by colonial observers, either because they were not seen or not valued. Historical sociologist Bruce Curtis framed this problem well in his book Ruling by Schooling in Quebec, emphasizing "People may be technically able to read and write and yet not care, or not be allowed to do so; they may be able to read or write well or ill. The key questions instead are, what are the occasions on which people must engage with print culture, and how do they do so?"27

This is where the longue durée proves a useful analytical framework. By examining formal structures of education over a broad geography and over the course of two hundred and fifty years, we can better account for some of the documentary challenges that have left gaps in the historical record. Where historians in the past have seen rupture, I would like to suggest the potential for qualified continuities.

As you read through this article, though, it is critical to remember its limitations. First, the numbers discussed here reflect only a small portion of the overall population of the nations discussed. In total, only about 2 per cent of these people attended a colonial college or charity school. In 1803, for example, when Annance set about founding his school at Odanak, he claimed that the Abenaki there did not value the school, although he persisted in building it anyway. ${ }^{28}$ We must acknowledge 
that references to these nations do not imply that they held a uniform perspective on the place of schooling and alphabetic literacy. Similarly, the focus of this article is on engagement with colonial systems of schooling and literacy. As an AngloCanadian scholar who takes a regional rather than a community-based approach, I am extremely reluctant to comment on the broader cultures or histories of education within these communities. My argument, then, should not be taken as an indication that all Kanien'kehá:ka, Abenaki, and Wendat were familiar with colonial systems of knowledge and schooling and certainly not that these systems were universally accepted or embraced. Rather, this article's tentative conclusions point towards some new questions for the history of colonial and missionary education in northeastern North America, proposing that alphabetic literacy, formal schooling, and the role of missionaries were critical forces with which Indigenous societies had to engage in a period earlier than historians have suggested in the past. In this way, the paper serves more as a prospectus for future research than a conclusive study, suggesting a need to situate this earlier context in the St. Lawrence valley into the more robust historiographies of Indigenous schooling and alphabetic literacies in places now part of the United States, the development of residential schools, and the emergence of colonial systems of schooling.

\section{Schooling and Alphabetic Literacy and the Eighteenth-Century Catholic Mission}

Two documents created between December 1772 and June 1773 suggest that more was going on in these communities than the historiography suggests. In December, two students at Moor's Indian Charity School penned a few lines for their teacher. The writing sample, according to Wheelock, was taken just weeks after the students' arrival at the school from the St. Lawrence valley. ${ }^{29}$ Later that summer, Paul Tsa8enhohi, the grand chief of the Wendat Nation at Lorette, sent a letter - written in French - to his nephew André Otiondi in Detroit asking what he should do with Otiondi's land..$^{30}$ Much like the earlier writing sample from the charity school, this one was finely penned. Although both documents could be challenged on grounds of their author's agency (the controlled nature of the school and the possibility that someone else penned the letter), the important point here is that they demonstrate Wendat engagement with roman orthographies. Just a decade after Britain claimed control over their lands, and while the Jesuits remained active in their communities, these documents suggest that these skills were drawn upon well before the school was built at Lorette in 1791 .

Although hardly sufficient evidence for drawing conclusions, these two documents resonate with Lisa Brooks's, Phillip Round's, and Hilary Wyss's depictions of writing in the mid-eighteenth century upper Connecticut valley. In her analysis of the 1747 Abenaki Petition at No. 2, for example, Brooks cautions historians against discounting Abenaki authorship. In a lineage that can be traced back to John Eliot's missionary efforts a century earlier, Brooks emphasizes how alphabetic writing was likely facilitated through the "Abenaki network of relations," tracing influences through Penacook, Mohican, and Kanien'kehá:ka histories. ${ }^{31}$ By focusing on more 
general themes, Round and Wyss make similar points, recognizing that practices of reading and writing "were tied to missionization, revitalization, and diplomacy." 32 The context of these historians' work, their focus on Abenaki territory and its proximity to the St. Lawrence valley and the lower Great Lakes, calls us to reconsider how we think about the eighteenth-century history of education in the St. Lawrence valley.

One of the key elements missing from most US-focused historiography is a grappling with New France. Although Brooks is attentive to French Catholic missionary influence in her first chapter, much of this literature has not adequately accounted for the role Catholic missionaries - and their Indigenous allies — played in alphabetizing oral languages or in creating and distributing manuscript books as part of their missionizing project. One important component that could be added to many of these studies is a deeper understanding of the alliance between the Jesuit order and the Kanien'kehá:ka, Abenaki, and Wendat living respectively at Kahnawake, Odanak, and Lorette. ${ }^{33}$ Although efforts to provide schooling declined at the dawn of the eighteenth century - especially as it related to the failure of their residential pedagogies - the Jesuits' continued presence in these communities and their emphasis on scholasticism, learning, and transcribing Indigenous languages caution against too hasty a dismissal.

The Jesuits, after all, were well known for their scholastic activity, particularly in colleges but also at a more elementary level among the European peasantry and in the global mission field. ${ }^{34}$ By the mid-eighteenth century, just before the British conquest of New France, the Jesuits ran nearly seven hundred schools around the world. France alone had ninety-two and a student body of approximately forty thousand. ${ }^{35}$ This was the world from which missionaries came, the culture to which they had taken their vows, and the framework that they brought with them across the Atlantic.

The missionaries living alongside the Kanien'kehá:ka, Abenaki, and Wendat had extensive experience teaching in the Jesuit collegiate system. According to Micah True, all Jesuits were required to spend two years teaching as part of their missionary formation. ${ }^{36}$ Many spent considerably more time working in schools and colleges. Men like Joseph Aubery, one of the longest serving Jesuits at Odanak, taught at the Jesuit College in Quebec for five years before his ordination in 1699. He was hardly unique. Of the twenty-four Jesuits listed in the Dictionary of Canadian Biography as having worked with the Wendat or Abenaki, eighteen had prior teaching experience, and six taught at the Jesuit College, where the missionaries had access to "the richest and most important library" in the colony. ${ }^{37}$

Although we do not know much about missionary activities in the St. Lawrence missions during the eighteenth century, seventeenth-century descriptions reveal fervent efforts to school Indigenous communities using European pedagogies. For the Jesuits, authority lay in the written word and alphabetic literacy was a foundational aspect of their interactions with Indigenous peoples as they worked to transform this space into a Catholic New France. Throughout the Jesuit Relations, missionaries emphasized the authority of writing over oral traditions. ${ }^{38}$ In the Relation for 1639 , Jerome Lalemant (who would later become superior in the colony) reported that writing, when combined with rhetoric, was the sole tool the Jesuits had available to 
win the Wendat over to their faith. "We have not here, nor can we have, either the power of constraint or the chains of benefits, to the extent that would be necessary to render these people entirely ours," the Jesuit wrote. "All our power lies at the end of our tongues, in the exhibition and production of our books and Writings, the effects of which they never cease to wonder at." ${ }^{39}$ Much like the Récollets, who were active in the region earlier, the Jesuits sought to establish their books and the technology of writing as the sole source of past authority. In their efforts to create a New France, they desired to make their gospel, and its complementary texts, the only authoritative ancestral voice. ${ }^{40}$

By assaulting oral traditions, the Jesuits made this form of literacy a central point of contest. This was particularly the case with the Wendat, on whom the Jesuits initially concentrated their efforts. The Relation of 1645-46 recounts a dispute between Christian and Traditional world views. During a Wendat council meeting, an old Christian was interrupted in his telling of the Christian creation story by the council's most senior member. The Elder chastised the Christian, warning him that he was wrong to repeat colonial fables. Instead he should tell Indigenous Wendat stories. After a period of imposed silence, where these more customary stories were told, the Christian man retorted:

I consented to listen to thee, and became silent without resistance... But seeing that thou tellest only fables, which have no foundation but lies, I have more right to speak than thou. Where are the writings which give us faith in what thou sayest? If each one is permitted to invent what he will, is it strange that we know nothing true... [The French] preserve from all antiquity the Sacred books, wherein the word of God himself is written, without permission to any one to alter it. $^{41}$

By the 1640s then, the Jesuits argued in their Relations that some Wendat understood the power that writing occupied for the French, integrating it into their concepts of power and authority. Although this technology did not supersede other traditions, and its influence was likely exaggerated by the missionaries for their Christian European audience, the challenge writing posed demonstrates that regardless of one's perspective on the event, these were issues at the heart of the Jesuit evangelical mission.

In addition to these divisive tactics, the Jesuits also used formal structures to teach literacy skills. Their practices built on earlier Catholic missionary efforts. Almost from their first arrival, French religious orders experimented with schooling as a tool for evangelization. Indeed, the Récollets, a Franciscan order invited to the colony by Champlain, had built a handful of schools by the late 1610s. Emma Anderson's work on the French-educated Innu boy Pastedechouan demonstrates the religious order's deep influence on at least a handful of youths. First a student at the missionary-run school at Tadoussac, this young boy chose to spend five years living at a Récollet monastery in Angers, France. Although the experience was devastating, alienating him from his culture in ways that resonate with those that experienced nineteenth-and 
twentieth-century residential schools, the centrality of schooling and writing to this experience should not be ignored. In their earliest efforts, Récollet missionaries aspired to introduce "young boarders to Christian mysteries, inculcate French and possibly Latin literacy, and serve as the seedbed for a native clergy." ${ }^{2} 2$ Similar to Eleazar Wheelock's efforts one hundred and fifty years later, even before Pastedechouan's departure for Europe, the Récollets sent back samples of his writing to demonstrate their influence within the Innu community. ${ }^{43}$ While in France, Pastedechouan and Gabriel Sagard, a Récollet missionary who would soon travel to the region, taught each other their languages. ${ }^{44}$ Pastedechouan returned to the St. Lawrence valley in 1625 able to speak, read, and write both Latin and French. ${ }^{45}$ Although in the nine years before his death Pastedechouan struggled to negotiate Innu and Christian identities, his experiences mark the significance of these early efforts. The central point is that alphabetic literacy and schooling — and the violent assimilative relationships that underpinned them - formed a basis for these early relationships developing from France's newly-achieved and more permanent presence in the region.

These efforts were renewed in the 1630s when the Jesuits replaced the Récollets. Primarily driven by the Jesuits and Ursulines, a female religious order dedicated to teaching children, these attempts were almost always divided by gender and involved relatively small numbers of students. Although most were unsuccessful, their approach was persistent over the course of the seventeenth century. Again, of all the Indigenous peoples in the region, the Wendat were most deeply involved. In the 1630 s, for example, Wendat children were taught reading and writing at a short-lived seminary in Notre-Dame-des-Anges, a seigneury just north and east of Quebec. ${ }^{46}$ In 1668, the Petit Seminaire opened its doors to six Wendat boys, although within five years they had left the school. The governor-general of New France, Louis de Baude de Frontenac, invited four Haudenosaunee boys to receive a Jesuit education in 1674, and Intendant Jacques Duchesneau adopted three Indigenous boys to rear with his sons (although they too quickly fled). ${ }^{47}$

Less apparent was schooling within mission communities. Duchesneau's correspondence suggests that some schooling also took place in this setting:

la mission de la montagne de Montreal a laquelle Mess ${ }^{\text {rs }}$ du seminaire de Saint Sulpice qui y sont establis donnent leurs soins avec grand succés et y ont formé de petites Escolles pour Instruire les enfans \& les accoutumer a nos manieres... Les Jesuittes outre La mission des Iroquois retirés a la prairye de La magdelaine pres de Montreal qui est tres florissante... ont aussi estably une Escolles pour Instruire \& franciser les enfans sauvages. ou encore celles des hurons de Lorette proche de Quebec, et une autre commancée a Sillery pour les abenaquis, \& touttes celles des nations montagnaises, algonquines, huronnes, Irroquoises, outaouases, e\&... ${ }^{48}$

Although we know little about whether these seventeenth-century schools resembled those that developed a century later, what is clear from Duchesneau's statements is that formal colonial education — targeting cultural and religious assimilation — had 
been instituted in a number of the communities allied with Catholic missionaries.

Documents about girls' schooling have better withstood the trials of time, although here too significant gaps remain. In the 1650s, the Augustinian sisters of the Hotel-Dieu schooled a handful of girls. ${ }^{49}$ More active (and persistent), the Ursuline order welcomed Indigenous girls to attend their school in Quebec. Of the sixty-nine Indigenous girls known to have attended, six were described as Abenaki, eight as Haudenosaunee, and eighteen as Wendat. ${ }^{50}$ Few of these students stayed longer than a few months; a handful remained for years. Of the nine girls who attended for more than five years, five had ties to the Wendat community at Lorette, suggesting a more sustained engagement from this local community.

Importantly, although most of these efforts failed, all of these examples were voluntary. There were certainly external and subtle forms of coercion pushing students to the schools, but none of these students was required to attend. Kathryn Labelle has interpreted Wendat attendance at the Ursuline school from within the context of their dispersal from their homelands, deriving from the convent's role in hosting Wendat families in the years following their migration to Quebec in the early 1650 s. Much like Anderson's analysis of Pastedechouan, Labelle takes seriously these people's agency in choosing to attend religious schools, especially drawing out the role schools played within the context of colonial dispossession. Within the emerging Wendat community around Quebec, Labelle suggests Catholic Wendat women worked to support struggling families in their community and among their French neighbours, leading to their engagement with the Ursulines. Far from being isolated, and reflecting women's important role in Wendat decision-making, girls who attended the school served important intermediary roles between the religious orders, French society, and their home community. ${ }^{51}$

This emphasis on the political (rather than religious or cultural) appeal for schooling, embedded within the context of growing colonial pressures on Indigenous nations, resonates strongly with the history of schooling in the Haudenosaunee Confederacy. In her work on Kanien'kehá:ka-Anglican relations at the turn of the nineteenth century, for example, Elizabeth Elbourne situates schooling as an institution through which some Kanien'kehá:ka used Christianity and written texts to negotiate their relationship with Britain. Carefully laying out the danger and controversy these institutions brought with them, which no doubt also existed in the St. Lawrence valley, Elbourne suggests that "it seems possible that control of Anglican liturgy and teaching continued to enable men such as Sahonwagy to develop local versions of Christianity, to maintain military alliances and possibly to challenge the authority of particular elites." ${ }^{2} 2$ Likewise, focusing on a similar period, Alyssa Mt. Pleasant demonstrates how the Haudenosaunee at Buffalo Creek used the principles of Guswenta (Two Row Wampum Belt) to incorporate American education. Importantly, the Guswenta principles of engaging with each other but not intermixing were specifically invoked in response to the cultural and territorial erosion brought about by the introduction of mission schools on Kanien'kehá:ka land and elsewhere. In this context, the perceived advantages of literacy and numeracy in counteracting the politics of dispossession were weighed carefully and only hesitantly engaged. At 
Buffalo Creek, schooling was a strategy framed to negotiate settler migration onto Haudenosaunee land and did not preclude the community's "commitment to maintaining customary educational practices." ${ }^{53}$ Rick Monture makes a similar argument in his study of Joseph Brant and the Six Nations of the Grand River. ${ }^{54}$

It is from within this context of alliance and negotiation that we might turn our attention to the eighteenth century. Although Jesuit correspondence declined over this period, a sign of the order's waning influence, a handful of eighteenth-century Jesuit letters signal that their instruction in mission villages continued. In a letter describing the Canadian mission in 1711, for example, Father Joseph Germain made mention of children's education in order to emphasize that it would not be discussed: "I speak not of the native children, whom our fathers educate in our missions." 55 Pointing to similar language from the 1640s, Micah True's analysis of the Relations as an oeuvre demonstrates well that it was not uncommon for the Jesuits to ignore subject matter that they felt was commonplace. ${ }^{56}$ The Jesuit Relations were primarily focused on communicating new and novel information, rather than the mundane routines of everyday life.

As Jesuit influence diminished, references to the education of children begin to reappear. Nearly on his deathbed, Augustin-Louis de Glapion, the last Jesuit superior, declared that the order was "no longer able to fulfill the stipulated obligations to instruct the natives and the young Canadians." 57 The Jesuits desired their property to be transferred to the general administration of the church for the instruction of Indigenous and French peoples. Peter Stephen de Ponceau hints at what these "stipulated obligations" might have looked like. During the American Revolution, he encountered an Abenaki man who claimed the Jesuits "had taught him reading and writing and many other things." 58 Taken alone, these examples seem trivial. When considered together, they hint that Jesuit efforts to school Indigenous people were more resilient than the historiography suggests. Whether scholastic or literary rather than religious instruction occurred or not is a question that needs to be more deeply studied but what these statements suggest is that rather than abandoning formal instruction in their missions, the Jesuits viewed teaching as important to their eighteenth-century work.

If missionary efforts persisted over the eighteenth century, we must then ask ourselves why students might have attended their instruction. In addition to the political pressures imposed by colonial encroachment, the approach taken by the Jesuits and Ursulines might have also had some appeal. Although missionary schooling certainly had an assimilative agenda, both religious orders sought to work within Indigenous cultures and languages. This reflexive position was a direct extension of Jesuit beliefs. Their pedagogical guide, the 1599 Ratio Studiorum, which was used through to the order's suppression, encouraged missionaries "to adapt their instruction to the character of the clientele and the demands of time and place." ${ }^{59}$ At both Lorette and the Kanien'kehá:ka town of Kahnawake (near Montreal), for example, the Wendat language, which — as an Iroquoian language — could be understood by students in both communities, was used for instruction. ${ }^{60}$ Indeed, Wendat continued as a language of instruction at Lorette well into the nineteenth century. ${ }^{61}$ Unlike later Euro-American 
attempts to restrict the use of Indigenous languages, this was not a central component of missionary work in this context.

The Jesuits also made a concerted effort to transcribe oral languages into alphabetic orthographies. As the works of Marie Battiste, Lisa Brooks, Germaine Warkentin, Hilary Wyss, and others have shown, these new orthographies likely built on older literacies embedded within Indigenous cultures, such as pictographs, wampum, and birchbark. ${ }^{62}$ Brooks provides a good summary of how alphabetic literacy was situated within these pre-existing writing practices:

Transformations occurred when the European system [of writing] entered Native space. Birchbark messages became letters and petitions, wampum records became treaties, and journey pictographs became written "journals" that contained similar geographic and relational markers, while histories recorded on birchbark and wampum became written communal narratives. All of these forms were prolific in the northeast long before Indian people began writing poetry and fiction. ${ }^{63}$

Transcribing language bridged the new to the old, creating continuity with past practices. It was likely that it was this new visualization of Indigenous languages, rather than just Latin or French, that the Jesuits taught as part of their curriculum in reading and writing. It was perhaps from this foundation - engaging with missionaries reading and writing in their own language - that some students later developed literacy skills in European languages.

This blending of writing practices can be clearly seen at both Lorette and Odanak at the end of the seventeenth century. No doubt under the direction of their allied missionaries, Catholics in both towns sent wampum belts to the celebrated cathedral at Notre-Dame de Chartres inscribed with the Latin messages: "VIRGINI PARITVRAE - VOTVM HVRONVM" and "MATRI VIRGINI ABNAQUAEI DD." ${ }^{44}$ Although the Jesuits may or may not have taught literacy skills directly, these belts demonstrate that such instruction may have occurred. Furthermore, if these skills were taught and passed along through community channels, likely through the women, as Labelle's work suggests, it is unlikely that the influence of these experiences would appear in the male-dominated colonial and missionary record.

The fabrication of these belts illustrates the cross-cultural conversations that must have taken place within these Jesuit-allied communities. Much like the relationship between Pastedechouan and Sagard in France, seventeenth-century Jesuits situated themselves both as teachers and learners. ${ }^{65}$ The evocative title of Micah True's book, Masters and Students, situates their position well, emphasizing the interdependency between the Jesuits' desire to work as both masters of the Christian faith but also as students of Indigenous languages and culture. Missionaries needed to gain competency in Indigenous languages in order to work within them. As such, the mission towns, particularly Lorette, were well-known linguistic training sites for newly-arrived missionaries or for those setting out to evangelize farther afield. In these communities, Jesuits preparing for the mission field transcribed Indigenous languages 
into alphabetic scripts, creating grammars and dictionaries from which they and their colleagues could learn. ${ }^{66}$

These Jesuit-created tools served a reflexive purpose as they increasingly became incorporated into village life. In the early nineteenth century, at least two Wendat families possessed seventeenth-century manuscript French-Wendat dictionaries. Initially written by the Jesuit Pierre-Joseph-Marie Chaumonot, over time they also seem to have been used and modified by the Wendat. ${ }^{67}$ Similarly, according to Nicolas Smith and Alice Nash, at Odanak, Abenaki Catholics recopied religious books in order to take them along hunting or to be distributed to missions further afield. ${ }^{68}$ By the nineteenth century, as their languages were increasingly threatened, people from both communities created similar texts in order to keep their language alive. In 1830, charity school alumnus Pierre Paul Osunkirhine, a protestant schoolteacher at Odanak, published an Abenaki spelling book, Kimzowi Awighigan; eight years later, Wendat notary Paul Picard Tsasenhohi created a hand-written hymn book in the Wendat language. ${ }^{69}$

These books likely reinforced alphabetic literacy skills. Their printing and widespread use after the Jesuit suppression demonstrates the continued influence of these orthographies, even after the missionaries' influence declined. Although I have not found the print run for Osunkhirine's text, we have some information about similar books printed in the St. Lawrence valley. In addition to Smith and Nash's study of the Jesuit missionary Joseph Aubery's Abenaki-language texts, in 1767 the Jesuit JeanBaptiste de la Brosse (who earlier served at Odanak) ordered three thousand spellers and two thousand prayer books printed in Innu-aimun, the language of the Innu people, who lived northeast of Quebec. ${ }^{70}$ As was the case at Odanak, when printed copies wore out, de la Brosse's students created manuscript copies for further circulation. Corrected versions of the prayer book were printed again in 1817 and 1844 . De la Brosse also had printed six hundred copies of an eight-page Abenaki primer, Akitami kakikemesudi-arenarag' auikhigan, in $1770 .{ }^{71}$ These are astonishing numbers that both reflect important continuities with earlier Jesuit missionary work as well as the later emphasis on schooling within these communities. Importantly, it was only after the arrival of the British in 1760 that the Laurentian colony had a printing press, offering the first opportunity to distribute these texts on a large scale.

Regardless of whether formal schools existed at this time, it seems clear from these examples that the workings of language and literacy were ever-present within the colonial culture of Jesuit missionary life in the mid-eighteenth century. Although at times my argument suggests that these efforts were taken up by the Jesuits' and Ursulines' Indigenous allies, it should not be mistaken as proposing that the Jesuits were even moderately successful in their endeavours to convert or school the Wendat, Abenaki, and Kanien'kehá:ka during the seventeenth and eighteenth centuries. Rather, I have tried to lay out a historical context from within which Abenaki, Wendat, and Kanien'kehá:ka peoples living in these places chose to attend colonial colleges and build day schools at the end of the eighteenth century. Similar to Indigenous peoples confronting English expansion, where this context has been much better developed, alphabetic systems of writing and schooling underpin 
France's colonization of Indigenous North America but were not directly engaged until after the empire's defeat.

\section{Other Strategies and Motivations for Engagement with Schools and Alphabetic Literacies}

Missionaries were part of this process, but we need to be careful not to assume that it was driven entirely by agents of empire. Although I argue above that the Jesuits cultivated a lasting culture of teaching and learning (possibly schooling) during the eighteenth century, Wendat, Abenaki, and Kanien'kehá:ka decisions to continue these traditions after the religious order was suppressed demonstrate that a much more complex process of education existed in these towns - especially given the long history, despite weak engagement, with formal schooling during the seventeenth century. Building on elusive references to undocumented Wendat and Haudenosaunee missionaries and teachers serving in a similar capacity during the seventeenth and eighteenth centuries, there is no reason that the students who attended these lateeighteenth century institutions would not have shared what they learned with others in their social and political networks. ${ }^{72}$ In fact, Jean Fittz Hankins suggests that, in the places transforming into colonial New England and New York just south of the St. Lawrence River, there were as many as 222 Indigenous men and women teaching school between 1698 and $1775 .^{73}$ The Jesuit and Ursuline schools and missions were just some among a number of sites where numeracy, reading, and writing skills could be taught.

By the end of the eighteenth century, Laurentian Indigenous peoples had good reason to cultivate alphabetic literacy skills. The northeast underwent a radical transition as British expansion went unchecked after 1763. In the years immediately following their conquest of New France and before any students went down to the charity school, Odanak, Kahnawake, and Lorette all complained about settler encroachment. ${ }^{74}$ Colonial migration into Abenaki territory was most acute. In the 1750s, the Abenaki felt comfortable demanding that the British prevent settlement in their territory. Two decades later, New England farms extended almost as far as the Canadian colony. ${ }^{75}$ French and British expansion into Indigenous territory was anchored by the legal codes of the Custom of Paris and the common law. Under both legal traditions, the distribution and legal occupation of land was governed by written deeds of concession and sale, or, under the British, through treaty. These were processes with which Indigenous nations on the edge of, and within, dense European settlements needed to, and did, address. ${ }^{76}$

Given that we know little about the specific dynamics of this history and its relationship to schooling, we should be careful in overemphasizing the role of missionaries. The argument here is that the creation of these schools was anchored in political rather than religious motivations. After more than a century of engaging with colonial and imperial systems of knowledge, there is no reason to discount the possibility that reading skills, if not writing skills, were taught and passed along to subsequent generations through relationships beyond those shaped by the mission. 
This is, after all, what happened following the Jesuit suppression.

It is highly unlikely that the Jesuit order's demise was the sole catalyst for the Kanien'kehá:ka, Wendat, and Abenaki decisions to send children to Moor's Indian Charity School. In fact, in Canada, the Jesuit missionaries had not yet left in 1773 when these communities sent students down to the school. Following the British conquest, the Jesuits were allowed to remain, although they could not recruit, causing the order to die a slow death. The last Jesuit at Odanak, Charles Germain, died in 1779; while the last missionary at Lorette, Etienne-Thomas Girault de Villeneuve, died in 1794 , three years after the school began. ${ }^{77}$ In both cases, Jesuit influence continued after these communities had sent their children down to the school in New Hampshire.

Although, for the most part, the remaining Jesuits resisted the charity school's Protestant influence, at least one missionary, Germain at Odanak, recognized the evolving geopolitical context and the role that schooling might play. According to the Protestant missionaries who recruited the first Abenaki students in 1774, the Jesuit "approved of our taking the Indian Boys, gave them some good Advice; and wished a prosperous Journey." ${ }^{\prime 8}$ Even at Lorette, where Girault opposed the school, it is possible that his opposition was half-hearted. An 1802 document suggests that the religious order approved of Sawatanen holding school on church grounds. ${ }^{79}$ This support is somewhat surprising in light of the fact that a decade earlier a local priest accused the Wendat schoolmaster of teaching heterodoxy. ${ }^{80}$ Indeed, given that the school at Lorette may not have had Bibles until the mid-1820s, the context in which these schools developed appears to be one in which religious differences between Protestant and Catholic were downplayed. ${ }^{81}$ In the face of a rapidly changing geopolitical context, denominational differences and religious concerns were seemingly set aside in favour of the educational opportunities for alphabetic and numerical skill development offered by colonial schooling.

To understand the context in which religious differences were set aside, we need to examine the eighteenth-century context within these towns. Although direct evidence of teaching and learning is difficult to find, the historical record provides brief glimpses into everyday life that suggest that, for at least some people, reading and writing were important. At Lorette, for example, by the mid-to-late eighteenth century at least a handful of people - like Paul Tsa8enhohi — sent letters or signed petitions. Similarly, from as early as 1733 , over fifty people took part in written notarial contracts. Although few signed the documents, Wendat engagement with French legal culture, especially as it relates to the colonial re-inscription of the Land, is suggestive of a growing need for reading and writing skills. ${ }^{82}$ Although limited to only two instances, the subscription lists from the Quebec Gazette, the city's first newspaper, are similarly indicative of alphabetic literacy. In the early 1790s, Sawantanen subscribed to the paper, as did Ferrier Vincent in $1826 .{ }^{83}$ When set beside the continued use of Chaumonot's seventeenth-century dictionaries, it seems clear that these skills were being cultivated at Lorette over the late eighteenth and early nineteenth centuries. Indeed, using signatures on a 1793 petition to the bishop of Quebec as an indicator of some degree of alphabetic literacy, it appears 
that as many as 20 per cent of the men in the community had some familiarity with writing. This is similar to the average literacy rate Allan Greer and Michel Verrette found in separate studies for the Canadian colony, but significantly higher than the rate I have calculated using a similar contemporary French petition from the area around Lorette. ${ }^{84}$

Although I have less evidence for Kahnawake and Odanak, these communities seem to be similar. In addition to Ponceau's conversation with the Abenaki man during the revolution, in 1773, Thomas Kendall, a charity school missionary, reported that much of his time at Kahnawake was spent "mending their pens \& seting their Coppys \& hearing them read" - implying that some youths in this town were actively learning to read and write and that some of them could indeed read. ${ }^{85}$ Six years later, an account book for the Indian Department indicates that a small amount of money was paid out for schooling the community's children. ${ }^{86}$ For both communities, colonial officials and missionaries printed resources for the teaching of reading and writing. In 1770, de la Brosse printed that eight-page primer for the Abenaki; a decade later, in 1781, the Indian Department had three hundred copies printed of $A$ Primer for the Use of the Mohawk Children. ${ }^{87}$ Although produced by outsiders, these publications point to the increasing weight given to reading and writing at the end of the eighteenth century.

It was from within this context - where reading and writing French or English were increasingly necessary skills in the expanding colonial world-that the Kanien'kehá:ka, Abenaki, and Wendat approached Moor's Indian Charity School. Jean-Pierre Sawaya and Jean Barman have interpreted this developing interest in formal schooling through the rising prominence of Anglo-American captive families within the Seven Fires Confederacy. Structured through the politics of alliance, the captive-oriented components of the confederacy sent its leaders' children - many of whom were descendants of captives - down to the charity school. When situated in the context I have established above, however, the interest these students took in the school looks somewhat different.

Although Sawaya's and Barman's explanations are useful and important, their more local focus and Sawaya's emphasis on Wheelock's motivations are inadequate for understanding the broader historical context shaping these decisions. At Lorette, for example, rather than having been recruited by charity school missionaries, who avoided the community due to feared Jesuit resistance, Sawatanen and his brother - who did not have these family connections to New England - encountered the charity school missionaries at Kahnawake as they made their way to meet William Johnson to request formal schooling. ${ }^{88}$ Twenty years later, they requested of the Crown access to formal schooling at the Catholic Petit Seminaire in Quebec as part of a series of petitions about access to land and resources. ${ }^{89}$ It seems clear that this request was indicative of how they perceived their relationship with the Crown. By 1797, the community was sending a handful of students to the school, an institution that had welcomed Indigenous students in the seventeenth century as well; much like that earlier period, though, the community removed the students in $1806 .{ }^{90}$ Interest in schooling — at least at Lorette — was broader than the captivity-focused arguments 
about the Seven Fires Confederacy's engagement with the charity school, and embedded in the broader regional culture of schooling I outlined above.

Although similar to other Indigenous communities in the St. Lawrence valley, the culture of schooling that developed within these nations was unique in the St. Lawrence valley. At this time, the colonial population's literacy rates and access to schools was in decline. ${ }^{91}$ There were only twenty schools operating in Quebec, Montreal, and Trois-Rivières. ${ }^{92}$ Interestingly, in 1792, one of these schools, the school at Berthier run by Louis Labadie, comprised " 44 Scholars, 14 poor, and five Savages," further suggesting that Indigenous engagement with schooling was much more complex than the historiography suggests. ${ }^{93}$ By mid-century — and despite a rising population - only 20 of the 123 parishes in the colony had a school, most teachers had received little training, and literacy was restricted mainly to urban elites and professionals. ${ }^{94}$ It was not until nearly the end of the second quarter of the nineteenth century that schools became common in the Laurentian countryside. ${ }^{95}$ Indeed, in the 1820s and 1830s, a handful of Wendat and Abenaki men from Lorette and Odanak were some of the first teachers in these European day schools. ${ }^{96}$

If the average settler had few formal educational opportunities as the eighteenth century progressed, then the Kanien'kehá:ka, Abenaki, and Wendat living in these communities were indeed fundamentally different from their French neighbours. Rather than resisting schooling and the development of alphabetic literacy skills, as the historiography suggests, some people in these communities had material incentives tied to the rapid Euro-American resettlement of their Lands to understand the written culture of the European newcomers. Perhaps, better put, the emergence of alphabetic literacy and schools in these communities was one of the few options these people had to confront the rapid changes taking place upon their Land. Unlike colonial settlers - most of whom were farmers - the principal economies of these communities and their need for diplomacy increasingly required familiarity with written texts. Within this context, schooling and the development of literacy skills became more, rather than less, important: the exact opposite of what we see within the colonial population in the St. Lawrence valley.

\section{Conclusions}

By looking at these communities and their interaction with colonial educational structures - particularly schooling — during a time of dramatic environmental and political change, we see important glimpses of continuity over the eighteenth century with earlier seventeenth-century attempts to school northeastern Indigenous peoples. The introduction of community-driven formal schooling in turn-of-the-nineteenthcentury Lorette and Odanak did not mark a radical shift. Rather, it reflected the culmination of over one hundred and fifty years of selective engagement (usually in the form of resistance) with colonial and missionary education. In choosing to attend the Protestant charity school, students from these putatively Catholic communities chose schooling over religious affiliation, a decision that is suggestive of their alliance-based motivations for interacting with missionaries in the earlier period. 
From this vantage point emerges a complex image of schooling in the St. Lawrence valley that resonates with emerging Indigenous intellectual traditions and deployments of schooling elsewhere in eighteenth- and early nineteenth-century North America. The lives of men like Sawatanen and Annance, among others, share much in common with those of the well-known eighteenth-century Mohegan scholar, Samson Occom, and the Haudenosaunee leader, Thayendenegea (also known as Joseph Brant), both of whom also attended the charity school. ${ }^{97}$ The history of alphabetic literacy and printing also aligns with contemporary Cherokee experiences of schooling, printing, and literacy. ${ }^{98}$ In other words, Jesuit missions allied with Indigenous nations no doubt involved evangelization and Christianity, but when we view their histories from a broader chronological and spatial perspective that moves beyond the constraints of the nation-state and better respects Indigenous lands, we see significant and new patterns of continuity that help us better understand Indigenous uses for, and applications of, colonial schooling; reframing our perspective away from missionary desires and towards a more complex understanding of the people living within these missionary-allied communities.

It is no coincidence that these patterns become clearer at the end of the eighteenth century. Waves of colonists migrating from New England and the American colonies and then from across the Atlantic created the conditions within which some Abenaki, Kanien'kehá:ka, and Wendat drew upon their nearly two hundred-year history of interaction with French and English colonial practices by using schooling and alphabetic literacy as a path for community survival.

\section{Notes}

Research for this paper was conducted with the support of a Social Sciences and Humanities Research Council postdoctoral fellowship and Insight Development Grant. The author would like to thank Jean Barman, Alan Corbiere, Susan Glover, Jean-François Lozier and Alison Norman for reading early drafts.

1 Henry L. Masta, "When the Abenaki Came to Dartmouth," Alumni Magazine (March 1929).

2 Jean Barman, Abenaki Daring: The Life and Writings of Noel Annance (Montreal and Kingston: McGill-Queen's University Press, 2016), ch. 2; Mathieu Chaurette, "Les premières écoles autochtones au Québec (MA thesis, Université du Québec à Montréal, 2011), 31; Masta, "When the Abenaki Came to Dartmouth"; Dartmouth College Archives (DCA), Vertical Files, "Odanak."

3 Stéphanie Boutevin demonstrates that literacy functioned quite differently in each of these communities by the mid-nineteenth century. It is my contention here, though, that these communities had similar trajectories in their early engagement with schooling. See Boutevin, « La Place et les Usages de l'Écriture chez les Hurons et les Abénakis » (PhD diss., Université du Québec à Montréal, 2011).

4 Chaurette, "Les premières écoles », 45-46; Vincent Ferrier to John Neilson, April 15, 1829, Library and Archives Canada, MG-24 B1, Vol. 6, ff. 425-428; John Wheelock to McClure, January 15, 1805, DCA, 805115.

5 For more on Sawatanen, see Jonathan Lainey and Thomas Peace, « Louis Vincent Sawantanan, premier bachelier autochtone canadien ", in Vivre la Conquête, Vol. 1, 
ed. Gaston Deschênes and Denis Vaugeois (Sillery: Septentrion, 2013), 204-214. A modified English version of this essay appears as "Louis Vincent Sawatanen: A Life Forged by Warfare and Migration," in Aboriginal History: A Reader, ed. Kristin Burnett and Geoff Read (Toronto: Oxford University Press, 2016), 106-116.

6 Barman, Abenaki Daring, 49.

7 Colin Calloway, The Indian History of an American Institution: Native Americans and Dartmouth (Hanover: University Press of New England, 2010), appendix. Although the Wendat only comprised three of these students, an additional five boys attended another colonial college, the Petit Seminaire in Quebec, between 1797 and 1806. See Centre de référence de l'Amérique française (CRAF), SME c. 36-38. For more on schooling at Odanak and Jeune-Lorette, see Chaurette, "Les premières écoles ".

8 For more on Kanien'kehá:ka schooling, see Keith Jamieson, History of Six Nations Education (Brantford: Woodland Indian Cultural Educational Centre, 1987); E. Jennifer Monaghan, Learning to Read and Write in Colonial America (Boston: University of Massachusetts Press, 2005), ch. 11; Elizabeth Elbourne, "Managing Alliance, Negotiating Christianity: Haudenosaunee Uses of Anglicanism in Northeastern North America, 1760s-1830s," in Mixed Blessings: Indigenous Encounters with Christianity in Canada, ed. Tolly Bradford and Chelsea Horton (Vancouver: UBC Press, 2016), 38-60.

9 Jean-Pierre Sawaya, for example, suggests a shift in the 1770s in how these communities approached schooling. By focusing more on the activities of New England captives and colonial missionaries, however, he misses an important opportunity to understand community motivations by probing their longer history more deeply. See Sawaya, «Les Amérindiens domiciliés et le protestantisme au XVIIIe siècle: Eleazar Wheelock et le Dartmouth College ", Historical Studies in Education/Revue d'histoire de l'éducation 22 (Fall 2010): 18-38; Barman, Abenaki Daring, ch. 2.

10 The clearest examples are Roger Magnuson, Education in New France (Montreal and Kingston: McGill-Queen's University Press, 1992), 62-63, 186-187; and Alain Beaulieu, Stéphanie Béreau, and Jean Tanguay, Les Wendats du Québec: Territoire, Économie et Identité, 1650-1930 (Quebec: Les éditions GID, 2013), 185; see notes that follow for additional examples.

11 Michel Verrette, L’Alphabétisation au Québec, 1660-1900 (Sillery: Septentrion, 2002), 117 and 119 . Verrette does not make this point explicitly; in fact, he actually suggests that Indigenous people probably should not be included (see 126), but in the charts found on 117 and 119 he includes the category "sauvage" alongside other social classes in the St. Lawrence valley. This juxtaposition clearly implies that the population was not literate.

12 Allan Greer, Mohawk Saint: Catherine Tekakwitha and the Jesuits (Toronto: Oxford University Press, 2005), 100; Robert Carney, "Aboriginal Residential Schools Before Confederation: The Early Experience," CCHA Historical Studies 61 (1995): 21. Carney points to the possibility of continuity with past local efforts but his tone is more speculative than authoritative, whereas Boutevin recognizes the possibility of early writing but assigns it to the religious sphere until the late eighteenth century when there is a clear uptake in writing as a political strategy. She discounts, however, the possibility that alphabetic literacy was part of village life when she emphasizes that " dans les deux siècles précédents, les autochtones de la vallée du Saint-Laurent n'avaient montré aucun signe, ou presque, d'intérêt pour apprendre à écrire ». See Boutevin, "La Place et les Usages de l'Écriture », 4, 65-67.

13 This historiographical framework has significant consequences for studies of the nineteenth century, which routinely fail to take Indigenous communities and education into account. See Bruce Curtis, Ruling by Schooling Quebec: Conquest to Liberal Governmentality - A Historical Sociology (Toronto: University of Toronto Press, 2012).

14 Micah True's Masters and Students demonstrates many of the problems with using these types of sources. In addition to ending their public dissemination in 1673, the Jesuit 
Relations also tended to avoid repetition of common experiences in the mission field, making schooling a subject that over time may have been left aside in the missionary reports. See Micah True, Masters and Students: Jesuit Mission Ethnography in SeventeenthCentury New France (Montreal and Kingston: McGill-Queen's University Press, 2015), 9-10, 156, 171.

15 Only eleven of the seventy-one volumes in Reuben Thwaites well-known collection of the Jesuit Relations address the period between 1673 and 1791; only five cover the eighteenth century. Reuben Gold Thwaites, ed. The Jesuit Relations and Allied Documents (JR) (Cleveland: Burrows Bros. Co., 1896-1901). Available online at http://puffin. creighton.edu/jesuit/relations/.

16 James Axtell, The Invasion Within: The Contest of Cultures in Colonial North America (New York: Oxford University Press, 1986), ch. 8; Margaret Connell Szasz, Indian Education in the American Colonies, 1607-1783 (Albuquerque: University of New Mexico Press, 1988); Cary Michael Carney, Native American Higher Education in the United States (New Brunswick, NJ: Transaction Publishers, 1999).

17 Carney, "Aboriginal Residential Schools Before Confederation"; Donald Smith, Sacred Feathers: The Reverend Peter Jones (Kahkewaquonaby) and the Mississauga Indians (Toronto: University of Toronto Press, 1987); Donald Smith, Mississauga Portraits: Ojibwe Voices from Nineteenth-Century Canada (Toronto: University of Toronto Press, 2013); J. R. Miller, Shingwauk's Vision: A History of Native Residential Schools (Toronto: University of Toronto Press, 1996); John Milloy, A National Crime: The Canadian Government and the Residential School System, 1879 to 1986 (Winnipeg: University of Manitoba Press, 1999); Blair Stonechild, The New Buffalo: The Struggle for Aboriginal Post-Secondary Education in Canada (Winnipeg: University of Manitoba Press, 2006).

18 I have intentionally capitalized the word "Land" to emphasize a broader definition than merely the ground upon which humans live. In doing so, I am drawing on Mishuana Goeman's exploration of the term in "From Place to Territories and Back Again: Centering Storied Land in the Discussion of Indigenous Nation-building," International Journal of Critical Indigenous Studies 1, no. 1 (2008): 23-34. In this article, Goeman challenges scholars to reflect critically on the word's meaning, moving beyond simplistic notions of property and location to better encompass and reclaim the meanings, relationships, politics, and rootedness underpinning the term's use by Indigenous Elders, intellectuals, and scholars.

19 This point is perhaps made most clearly when we look at the proliferation of books about northeastern Indigenous intellectuals of the early nineteenth century. In addition to Occom, we could also point to Jean Barman, Abenaki Daring; Philip F. Gura, The Life of William Apess, Pequot (Chapel Hill, NC: University of North Carolina Press, 2015); Laura J. Murray, To Do Good to my Indian Brethren: The Writings of Joseph Johnson, 1751-1776 (Amherst, MA: University of Massachusetts Press, 1998); Michael Oberg, Professional Indian: The American Odyssey of Eleazar Williams (Philadelphia: University of Pennsylvania Press, 2015); Jonathan Lainey and Thomas Peace, "Louis Vincent Sawatanen: A Life Forged by Warfare and Migration”; Smith, Sacred Feathers; Smith, Mississanga Portraits.

20 Lisa Brooks, The Common Pot: The Recovery of Native Space in the Northeast (Minneapolis, MN: University of Minnesota Press, 2008), 86-90; Linford Fisher, The Indian Great Awakening: Religion and the Shaping of Native Cultures in Early America (New York: Oxford University Press, 2012).

21 Fisher, The Indian Great Awakening, 163.

22 Elbourne, "Managing Alliance, Negotiating Christianity;" Jamieson, History of Six Nations Education; Monaghan, Learning to Read and Write; Rick Monture, We Share Our Matters: Two Centuries of Writing and Resistance at Six Nations of the Grand River (Winnipeg: University of Manitoba Press, 2015), 39; J. Donald Wilson, " No 
Blanket to be Worn in School': The Education of Indians in Nineteenth-Century Ontario," in Indian Education in Canada, Vol. 1: The Legacy, ed. Jean Barman, Yvonne Hebert, and Don McAskill (Vancouver: UBC Press, 1986), 64-85; Gus Richardson, "Sahonwagy," Dictionary of Canadian Biography (DCB): http://www.biographi.ca/en/ bio/sahonwagy_4E.html.

23 Hope MacLean, "A Positive Experiment in Aboriginal Education: The Methodist Ojibwa Day Schools in Upper Canada, 1824-1833," Canadian Journal of Native Studies 22, no. 1 (2002): 46.

24 For a more flexible definition and understanding of orality and literacy, see Germaine Warkentin, "In Search of 'The Word of the Other': Aboriginal Sign Systems and the History of the Book in Canada," Book History 2, no. 1 (1999): 1-27; Germaine Warkentin, "Dead Metaphor or Working Model? 'The Book' in Native America," in Colonial Mediascapes: Sensory Worlds of the Early Americas, ed. Matt Cohen and Jeffery Glover (Lincoln, NE: University of Nebraska Press, 2014); Brooks, The Common Pot.

25 Brooks, xxvii.

26 Hilary Wyss, "Mary Occom and Sarah Simon: Gender and Native Literacy in Colonial New England," New England Quarterly 79, no. 3 (September 2006): 387-412.

27 Curtis, Ruling by Schooling Quebec, 11.

28 François Annance to John Wheelock, October 5, 1803, DCA 803555.

29 The documents can be found in DCA 772678.4 and 772690. They have been reproduced in Phillip Round, Removable Type: Histories of the Book in Indian Country, 1663-1880 (Chapel Hill, NC: University of North Carolina Press, 2010), 63; and Sawaya, «Les Amérindiens domiciliés et le protestantisme au XVIIIe siècle », 31.

30 Paul Tsa8enhohi to André Otiondi, June 11, 1773, Université de Montréal, Collection Baby, U 5266.

31 Brooks, The Common Pot, 46-50.

32 Round, Removable Type, 63. See also Hilary E. Wyss, English Letters and Indian Literacies: Reading, Writing, and New England Missionary Schools (Philadelphia: University of Pennsylvania Press, 2012).

33 I have deliberately used the word alliance here to emphasize how these communities were affiliated with the Jesuits but remained self-governing. See Allan Greer's description of Kahnawake in Mohawk Saint, ch. 4; Elizabeth Elbourne frames the Kanien'kehá:kaAnglican relationship similarly in "Managing Alliance, Negotiating Christianity."

34 Peter Goddard, "Converting the 'Sauvage': Jesuit and Montagnais in SeventeenthCentury New France," Catholic Historical Review 84, no. 2 (April 1998): 219-239.

35 Allan P. Farrell, trans. and ed., The Jesuit Ratio Studiorum of 1599 (Washington, DC: Conference of Major Superiors of Jesuits, 1970), iii. Accessed February 2015; available online at: http://www.bc.edu/sites/libraries/ratio/ratio1599.pdf.

36 True, Masters and Students, 46.

37 See $D C B$ entries for: Joseph Aubery; Louis D’Avaugour; Thierry Bescheffer; Jacques Bigot; Vincent Bigot; Martin Bouvart; Jean-Baptiste de la Brosse; Pierre Cholenec; Claude Chauchetière; Pierre-Joseph-Marie Chaumonot; Michel-Germain de Couvert; Julien Garnier; Augustin-Louis de Glapion; François Vaillant de Gueslis; Pierre de Lagrené; Étienne Lauverjat; Pierre de Lauzon; Gabriel Marcol; Pierre Millet; PierrePhilippe Poitier; Pierre Raffeix; Armand de la Richardie; Pierre-Joseph-Antoine Roubaud; Jacques-François Le Sueur. On the Jesuit library at Quebec, see Gilles Gallichan, "The Library at the Collège des jésuites," in The History of the Book in Canada. Vol. 1: Beginnings to 1840, ed. Patricia Lockhart Fleming, Gilles Gallichan, and Yvan Lamonde (Toronto: University of Toronto Press, 2004).

38 Peter A. Dorsey, "Going to School with the Savages: Authorship and Authority among the Jesuits of New France," William and Mary Quarterly, Third Series, 55, no. 3 (July 1998): 399-420. See, for example, the Relation of 1639, JR, Vol. 17, 135; part of Bresani’s “Breve Relatione," JR, Vol. 39, 149. 
39 Relation of $1639(J R)$.

40 Part of Bresani's “Breve Relatione," JR, Vol. 39, 149.

41 Relation of 1645/46, JR, Vol. 30, 61-63.

42 Emma Anderson, The Betrayal of Faith: The Tragic Journey of a Colonial Native Convert (Cambridge, MA: Harvard University Press, 2007), 76.

43 Ibid., 63.

44 Ibid., 103.

45 Ibid., 95.

46 Magnuson, Education in New France, 49.

47 Ibid., 61.

48 Duchesneau au ministre, novembre 10, 1679, Centre Archives d'Outre-Mer (CAOM), C11A Vol. 5, f. 49v-50. Emphasis added. I am grateful to Jean-François Lozier, curator of Canadian history before 1800 at the Canadian Museum of History for drawing my attention to this reference.

49 A. M. J. Saint-Ignace, Les Annales de l'Hôtel-Dieu de Québec, 1636-1716 (Quebec: Hôtel-Dieu de Québec, 1939), 85, 89, 95.

50 Registre des Entrées et Sorties des Petites Filles Françaises et Sauvages de 1641, Archives du Monastère des Ursulines de Québec (AMUQ), Pensionnat 1/NG.1.1.1; Marcel Trudel, Les écolières des Ursulines de Québec, 1639-1686: Amérindiennes et Canadiennes (Montreal: Éditions Hurtubise, 1999).

51 Kathryn Labelle, Dispersed but not Destroyed: A History of the Seventeenth-Century Wendat People (Vancouver: UBC Press, 2012), ch. 9.

52 Elbourne, "Managing Alliance, Negotiating Christianity," 49.

53 Alyssa Mt. Pleasant, "Guiding Principles: Guswenta and the Debate over Formal Schooling at Buffalo Creek, 1800-1811," in Indian Subjects: Hemispheric Perspectives on the History of Indigenous Education, ed. Brenda J. Child and Brian Klopotek (Santa Fe, NM: School for Advanced Research, 2014), 127.

54 Monture, We Share Our Matters, ch. 1.

55 Letter by Father Joseph Germain regarding the Canadian mission in the year 1711, JR, Vol. 66, 209-211.

56 True, Masters and Students, 156.

57 Letter of Reverend Father de Glapion to Monsieur Louis Germain [Langlois], fils, $J R$, Vol. 71, 101-103.

58 James L. Whitehead, "Notes and Documents: The Autobiography of Peter Stephen Du Ponceau," Pennsylvania Magazine of History and Biography 61, no. 1 (1939): 221-223.

59 Magnuson, Education in New France, 18.

60 Greer, Mohawk Saint, 100.

61 Chaurette, "Les premières écoles ", 36.

62 Marie Battiste, "An Historical Investigation of the Social and Cultural Consequences of Micmac Literacy" (PhD diss., Stanford University, 1983); Brooks, The Common Pot; Warkentin, "In Search of 'The Word of the Other' "; Warkentin, "Dead Metaphor or Working Model?”; Hilary Wyss, Writing Indians: Literacy, Christianity, and Native Community in Early America (Boston: University of Massachusetts Press, 2003).

63 Brooks, The Common Pot, 13.

64 Boutevin, «La Place et les Usages de l'Écriture », 38-39; see also Jonathan Lainey, La 'Monnaie des Sauvages': Les colliers de wampum d'hier à aujourd'hui (Sillery: Septentrion, 2004), 66-68. Translated to French by Lainey as "Vœu des Hurons à la Vierge qui doit enfanter" ("A votive from the Wendat for the Virgin who is to give birth") and from the Commission Franco-Quebécoise sur les Lieux de Mémoire Communs as "Don des Abénaquis à la Vierge Mère" ("A Gift from the Abenaki to the Virgin Mother"). See "Wampum - ex-voto" memoires-ameriquefrancaise.com, http://www.memoiresameriquefrancaise. com/fiche.php?id=63\&champ $=\&$ start $=6 \&$ startaff $=0$. 
65 True, Masters and Students, ch. 2.

66 Two accessible examples are Pierre-Joseph-Marie Chaumonot's 1640 dictionary, available through the Internet Archive: accessed February 2015, https://archive.org/ details/frenchhurondicti00chau; and Robert Toupin, ed. Les Écrits de Pierre Potier (Ottawa: Les Presses de l'Université d'Ottawa, 1996).

67 CRAF, SME MS-59, Radices linguae huronicae. On the first page of this manuscript is written: "Ce livre apar tien aetienne hurron de lorrette de 18 Du mois 1815. Cantique hurron de lorrette. patriarche "; CRAF, SME MS-62, Dictionnaire Huronne. On the first page of this manuscript appears: "Ce document m’a été légué par mon Père Paul Tahourhenché grand-chef de la Tribu Huronne établie en 1697 à N.D. de la Jeune Lorette, près Québec. Mon père le tenait de sa mère 'La8inonkie' épouse de Paul 'Onda8enhout' vers 1871 a l'age de 84 ans, à la Jeune Lorette. Ce document passe dans ma famille pour avoir été écrit par le R. P. Chaumonot. 'Paul (Picard) Tsa8enhohi. N.P.' ». CRAF SME MS-60, Dictionnaire français-huron also has what appear to be Wendat names written on the inside cover, but the chain of custody is not as apparent as it is for MS-59 and MS-62.

68 Nicolas Smith and Alice Nash, "La Linguistique liturgique du père Aubery ", Recherches Amérindiennes au Québec 33, no. 2 (2003): 11.

69 CRAF, SME 13/MS-66, Receuil de chants Hurons.

70 Quotation from Léo-Paul Hébert, "Jean-Baptiste de la Brosse," DCB; see also Joyce M. Banks, "And not hearers only': Books in Native Languages," in History of the Book in Canada, vol. 1, ed. Fleming et al., 280.

71 Banks, "And not hearers only', 280.

72 There is reference to Indigenous people serving in this capacity in the Jesuit Relations. See, for example, "The Huron Mission at Notre Dame de Lorette, during the year 1675 ," $J R$, Vol. 60, 25-29. Elbourne makes a similar observation in her study of the Kanien'kehá:ka-British alliance; see pages 43 and 48.

73 Jean Fittz Hankins, "Bringing the Good News: Protestant Missionaries to the Indians of New England and New York, 1700-1775" (PhD diss., University of Connecticut, 1993), 171, note 17; 204-214; appendices 2, 3, and 14.

74 Council minutes, May 8, 1767, United Kingdom National Archives (UKNA), CO 42, Vol. 27, f. 186v-188v; from Daniel Claus, August 22, 1767, The Papers of Sir William Johnson, Vol. 5, ed. James Sullivan et al. (Albany, NY: University of the State of New York, 1927), 635.

75 Gordon Day, "The Indian Occupation of Vermont," Vermont History 33, no. 3 (July 1965): 371; see also Gordon Day, The Identity of the St. Francis Indians (Ottawa: National Museum of Canada, 1981), 65, 117; Andrew Judson to Wheelock, October 7, 1777, DCA 777559; "The Present State \& Situation of the Indian Tribes in the Province of Quebec," May 1779, DCA 779301. See also Brooks, The Common Pot, ch. 1 .

76 For examples, see Emerson Baker " 'A Scratch with a Bear's Paw': Anglo-Indian Land Deeds in Early Maine," Ethnohistory 36 (Summer 1989): 235-256; Jean M. O’Brien, Dispossession by Degrees: Indian Land and Identity in Natick, Massachusetts, 1650-1790 (New York: Cambridge University Press, 1997).

77 Micheline D. Johnson, "Charles Germain," DCB.

78 Appendix: A Short Account of the Mission of the Reverend Mr. Levi Frisbie, Mr. James Dean, and Mr. Thomas Kendall, to the Indians in the Province of Quebec, Being an Abstract from the Journal of the Former, 1774. In Eleazar Wheelock, A Continuation of the Narrative of the Indian Charity School (Hartford, CT: Ebenezer Watson, 1775), 53.

79 Louis Vincent school master troubled in the possession of the presbytere at Lorette by the marguilliers, June 8,1802 , Bibliothèque et Archives Nationales du Québec à Québec (BANQ), Fonds Ministère des Terres et Forêts, Gestion des terres publiques, Biens des Jésuites, E21, S64, SS5, SSS2, D690-84. 
80 Lettre de Mr. Derome, ptre, mars 30, 1792, Archives de l'Archidiocèse de Québec (AAQ), 61, Charlesbourg, CD I-8.

81 Thaddeus Osgood, The Canadian Visitor Communicating Important Facts and Interesting Anecdotes Respecting the Indians and Destitute Settlers in Canada and the United States of America (London: Hamilton and Adams, [1829?]), 23-24. Too much should not be made of this point, however. Mathieu Chaurette's work well demonstrates that religious tensions were central to fights over schooling during the 1820s. See Chaurette, "Les premières écoles autochtones au Québec ", ch. 4.

82 See Thomas Peace, "Two Conquests: Aboriginal Experiences of the Fall of New France and Acadia" (PhD diss., York University, 2011), part two and appendix.

83 BANQ, Imprimerie Neilson, P193.

84 Précis des conventions entre les Hurons du village de Lorette et une partie des habitants de Charlesbourg, novembre 11, 1793, AAQ, 61 CDI-177A à E; Allan Greer, "The Pattern of Literacy in Quebec, 1745-1899," Histoire Sociale/Social History 11, no. 22 (1978): 295-335; Verrette, L'Alphabétisation au Québec.

85 Colin Calloway, The Indian History of an American Institution: Native Americans and Dartmouth (Hanover, NH: University Press of New England, 2010), 33.

86 CRAF, MS (cahier) 148: Affaires Indiennes sous le Colonel Guy Johnson, May 27, 1779.

87 Banks, " 'And not hearers only'."

88 Wheelock to Trustees, October 22, 1772, DCA 772572.

89 At the Council Chambers in the Bishop's Palace, August 15, 1791, CRAF, SME 1/2/12.

90 De Salaberry provides notice that the Huron council was removing their children from the seminary. July 5, 1806, CRAF, SME 1/2/12c.

91 Verrette, L'Alphabétisation au Québec, 95-96, 161. See also Curtis, Ruling by Schooling Quebec, 52-57.

92 Curtis, Ruling by Schooling Quebec, 53.

93 Montreal Gazette/Gazette de Montreal, March 15, December 6, 1792; November 7, 1793, as cited in Curtis, Ruling by Schooling Quebec, 57.

94 Greer, "The Pattern of Literacy in Quebec," 334; Magnuson, Education in New France, 86.

95 Anthony Di Mascio, "Forever Divided? Assessing the 'National' Question and the Governance in Education through a Re-examination of Québec's 1789 Report on Education," McGill Journal of Education 42, no. 3 (Fall 2007): 463-472.

96 Chaurette, "Les premières écoles autochtones au Québec ", 35.

97 Joanna Brooks, ed. The Collected Writings of Samson Occom, Mohegan: Leadership and Literature in Eighteenth Century Native America (New York: Oxford University Press, 2006), 28-39; Rick Monture, We Share Our Matters, ch. 1.

98 See Wyss, English Letters and Indian Literacies. 